\title{
Achyrocline satureioides (Lam.) DC (Asteraceae) Extract-Loaded Nanoemulsions as a Promising Topical Wound Healing Delivery System: In Vitro Assessments in Human Keratinocytes (HaCaT) and HET-CAM Irritant Potential
}

\author{
Lucélia Albarello Balestrin ${ }^{1}$, Tainá Kreutz ${ }^{1}$, Flávia Nathiely Silveira Fachel ${ }^{1}$, Juliana Bidone ${ }^{2}$, \\ Nicolly Espindola Gelsleichter ${ }^{3}$, Letícia Scherer Koester ${ }^{1}$, Valquiria Linck Bassani ${ }^{1}$, Elizandra Braganhol ${ }^{3,4}$, \\ Cristiana Lima Dora ${ }^{5}$ (D) and Helder Ferreira Teixeira ${ }^{1, *}$
}

check for
updates

Citation: Balestrin, L.A.; Kreutz, T.; Fachel, F.N.S.; Bidone, J.; Gelsleichter, N.E.; Koester, L.S.; Bassani, V.L.; Braganhol, E.; Dora, C.L.; Teixeira, H.F. Achyrocline satureioides (Lam.) DC (Asteraceae) Extract-Loaded Nanoemulsions as a Promising Topical Wound Healing Delivery System: In Vitro Assessments in Human Keratinocytes (HaCaT) and HET-CAM Irritant Potential. Pharmaceutics 2021, 13, 1241. https://doi.org/10.3390/ pharmaceutics13081241

Academic Editor: Ana Melero

Received: 15 June 2021

Accepted: 28 July 2021

Published: 12 August 2021

Publisher's Note: MDPI stays neutral with regard to jurisdictional claims in published maps and institutional affiliations.

Copyright: (c) 2021 by the authors. Licensee MDPI, Basel, Switzerland. This article is an open access article distributed under the terms and conditions of the Creative Commons Attribution (CC BY) license (https:// creativecommons.org/licenses/by/ $4.0 /)$.
1 Programa de Pós-Graduação em Ciências Farmacêuticas, Universidade Federal do Rio Grande do Sul, Porto Alegre 90610-000, Brazil; luceliaalbarello@gmail.com (L.A.B.); tainakreutz@gmail.com (T.K.); flavia.fachel@ufrgs.br (F.N.S.F.); leticia.koester@ufrgs.br (L.S.K.); valquiria.bassani@ufrgs.br (V.L.B.)

2 Curso de Farmácia, Centro de Ciências Químicas, Farmacêuticas e de Alimentos, Universidade Federal de Pelotas, Pelotas 96010-900, Brazil; julianabidone@gmail.com

3 Programa de Pós-Graduação em Biociências, Universidade Federal de Ciências da Saúde de Porto Alegre, Porto Alegre 90050-170, Brazil; nicolly_3@hotmail.com (N.E.G.); elizbraganhol@yahoo.com.br (E.B.)

4 Instituto de Cardiologia do Rio Grande do Sul/Fundação Universitária do Instituto de Cardiologia (IC-FUC), Porto Alegre 90040-371, Brazil

5 Programa de Pós-Graduação em Ciências da Saúde, Laboratório de Nanotecnologia, Faculdade de Medicina, Universidade Federal do Rio Grande, Rio Grande 96203-900, Brazil; cristianadora@gmail.com

* Correspondence: helder.teixeira@ufrgs.br

\begin{abstract}
Achyrocline satureioides (Lam.) DC Asteraceae extracts (ASEs) have been investigated for the treatment of various skin disorders. This study reports the effects of ASE-loaded nanoemulsions $\left(\mathrm{NE}_{\mathrm{ASE}}\right)$ on the cellular viability, death by necrosis, and migration of immortalized human keratinocytes (HaCaT cell line), as well as the irritant potential through the hen's egg chorioallantoic membrane test (HET-CAM). NE ASE exhibited a polydispersity index above 0.12 , with a droplet size

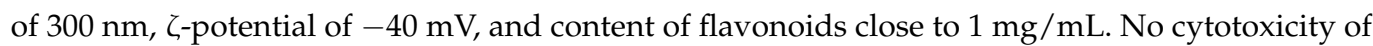
the ASE was observed on HaCaT by MTT assay (up to $10 \mu \mathrm{g} / \mathrm{mL}$ ). A significant increase of HaCaT viability was observed to $\mathrm{NE}_{\mathrm{ASE}}$ (up to $5 \mu \mathrm{g} / \mathrm{mL}$ of flavonoids), compared to treatment with the ASE. The necrosis death evaluation demonstrated that only $\mathrm{NE}_{\mathrm{ASE}}$ did not lead to cell death at all the tested concentrations. The scratch assay demonstrated that $\mathrm{NE}_{\mathrm{ASE}}$ was able to increase the cell migration at low flavonoid concentrations. Finally, the HET-CAM test proved the non-irritative potential of $\mathrm{NE}_{\mathrm{ASE}}$. Overall, the results indicate the potential of the proposed formulations for topical use in wound healing, in view of their promising effects on proliferation and migration in keratinocytes, combined with an indication of the absence of cytotoxicity and non-irritating potential.
\end{abstract}

Keywords: Achyrocline satureioides extract; flavonoids; nanoemulsion; topical nanosystem; wound healing; cell viability and migration; human keratinocytes (HaCaT); HET-CAM

\section{Introduction}

A considerable number of medicines that are based on bioactive compounds from medicinal plants are available on the pharmaceutical market. Such medicines contain drugs isolated from medicinal plant extracts or synthesized from compounds identified from these plant extracts [1]. However, despite the difficulties in relating the pharmacological activity with a specific compound or class of compounds and in elucidating the mechanism of action involved, phytomedicines containing crude plant extracts are widely used in clinical practice [2]. These products contain a variety of compounds that can interact with 
multiple targets, leading to additive and/or synergistic effects. Such effects have been widely suggested in well-documented and widely discussed scientific literature [3-6].

Extracts of Achyrocline satureioides (Lam.) DC (Asteraceae) (ASEs), a native medicinal plant in the southeast region of South America, have been widely investigated in different in vitro and in vivo studies [7]. To date, the potential activity of these extracts for various skin disorders has been widely described in view of the promising results obtained in different biological models, including antioxidant [8], anti-inflammatory [9,10], and antiherpes properties [11,12]. In a preliminary study with plants popularly used for wound healing, both aqueous by decoction and ethanolic by maceration $(3 \times 24 \mathrm{~h})$ ASEs showed the ability to increase cell proliferation in keratinocyte (HaCaT) and fibroblast (MRC-5) cell lines [13]. These results are promising as a stimulus in cell proliferation in vitro is indicative of a possible healing activity for this extract, which corroborates the arguments for its traditional use. Pereira and co-workers (2017) [14] demonstrated in vivo that ASE, when incorporated into an ointment, was able to promote a better renewal of collagen compared to the control groups, which is essential for complete wound healing.

The presence of several phytochemicals has been described in ASE extracts, including phenolic acids, chalcones, coumarins, polysaccharides, and polyacetylenes. Nevertheless, in most cases, the biological activities have been related to the presence of the flavonoid aglycones quercetin (QCT), luteolin (LUT), and 3-O-methylquercetin (3MQ) in the extracts obtained from the aerial parts of the plant, using organic solvents $[8,10,15-17]$. However, the poor water solubility of the flavonoid aglycones could limit their incorporation into topical products (generally presenting a hydrophilic nature), as well as the permeation and retention of these compounds through the skin. To circumvent this drawback, our research group has patented an original procedure to incorporate the main flavonoid aglycones from ASE into lipid-nanoemulsions by means of a spontaneous emulsification procedure [18]. This procedure allows the simultaneous incorporation of QCT, LUT, and $3 \mathrm{MQ}$ into monodispersed nanosized emulsions (200 nm range) [19]. Previous results have shown the distribution and accumulation of these flavonoids in porcine ear skin layers from nanoemulsions using Franz-type diffusion cells [12,20].

In this study, we present new evidence of the potentiation of the healing activity of this extract by its incorporation into a topical nanosystem. We investigated in vitro the effect of an ASE-loaded nanoemulsion on cell viability by MTT assay, cell death by necrosis by means of propidium iodate incorporation, and cell migration by the scratch assay in keratinocytes (HaCaT cell line). Finally, the irritant potential was determined with the hen's egg chorioallantoic membrane test (HET-CAM).

\section{Materials and Methods}

\subsection{Materials and Reagents}

Egg-lecithin (Lipoid E-80 ${ }^{\circledR}$ ), polysorbate 80, and vitamin E were obtained from Lipoid $\mathrm{GmbH}$ (Ludwigshafen, Germany). Dulbecco's modified Eagle's medium (DMEM), 3,(4,5dimethyl)-2,5diphenyl-tetrazolium bromide salt (MTT), and propidium iodide (PI) were purchased from Sigma-Aldrich Co. (St. Louis, MO, USA). Fetal bovine serum (FBS) and trypsin solution were obtained from Gibco (Grand Island, NE, USA). Methanol (J.T. Baker, Center Valley, PA, USA), acetonitrile (Tedia Brasil, Rio de Janeiro, Brazil), and phosphoric acid (Merck, Darmstadt, Germany) were of analytical grade and were used for the analysis by HPLC.

Dried inflorescences of Achyrocline satureioides were acquired from Centro Pluridisciplinar de Pesquisas Químicas, Biológicas e Agrícolas (CPQBA) da Universidade Estadual de Campinas (São Paulo, Brazil), and a sample of the species was deposited in the herbarium of the same institution (number 308). The research with genetic material from Brazilian biodiversity was registered in the SisGen (Sistema Nacional de Gestão do Patrimônio Genético e do Conhecimento Tradicional Associado) with number A8CA9A8. 


\subsection{Preparation of A. satureioides Extract (ASE)}

Initially, the inflorescences of the plant were manually cleaned and ground in a hammer mill. The ASE was obtained by maceration in ethanol $80 \%(v / v)$ for a period of eight days using a plant:solvent ratio of $7.5 \%(w / v)$, according to the method of Bidone et al. (2014) [19]. The extract was then pressed, filtered, and stored in the dark at $-20{ }^{\circ} \mathrm{C}$. The final content of the extract was $1 \mathrm{mg} / \mathrm{mL}$ of total flavonoids.

\subsection{Flavonoid Determination by Ultra-Fast Liquid Chromatography (UFLC)}

The content of flavonoids QCT, LUT, and 3MQ was determined in the ASE and the developed formulation (as total flavonoids) using validated ultra-fast liquid chromatography (UFLC), as previously described by Balestrin et al. (2020) [21]. The analyses were performed on a Shimadzu Prominence system device coupled with photodiode array (PDA) detection and an automatic injector controlled by LC-Solution Multi PDA software (Kyoto, Japan). The stationary phase was composed of a Phenomenex Luna column C18 (Phenomenex, $100 \times 2.0 \mathrm{~mm}$ i.d.; particle size $2.5 \mu \mathrm{m}$ ) guarded by an in-line pre-column Ultra KrudKatcher filter (Phenomenex, Torrance, CA, USA). The mobile phase consisted of methanol:phosphoric acid 1\% (48:52) in isocratic mode. The flow of the mobile phase was $0.3 \mathrm{~mL} / \mathrm{min}$, and the volume of injection was $4 \mu \mathrm{L}$. The wavelength was adjusted to $362 \mathrm{~nm}$, and the analysis was carried out at $40^{\circ} \mathrm{C}$.

\subsection{Preparation of A. satureioides Extract-Loaded Nanoemulsions}

Nanoemulsions containing ASE ( $\mathrm{NE}_{\mathrm{ASE}}$ ) were prepared by a spontaneous emulsification method, as described by Bidone et al. (2014) [19]. Briefly, the organic phase, consisting of $A$. satureioides ethanolic extract, egg-lecithin, vitamin E, fixed oil (medium chain triglycerides), and ethanol, was poured into the aqueous phase, composed of polysorbate 80 and water, under magnetic stirring for $30 \mathrm{~min}$. Afterwards, the ethanol was removed, and the formulation was concentrated by evaporation under reduced pressure at $40{ }^{\circ} \mathrm{C}$, up to $1 \%(w / v)$ of $A$. satureioides dry residue. Nanoemulsions without extract (blank nanoemulsion- $\mathrm{NE}_{\mathrm{B}}$ ) were also prepared as a control.

\subsection{Physicochemical Characterization of the Nanoemulsions}

$\mathrm{NE}_{\mathrm{ASE}}$ and $\mathrm{NE}_{\mathrm{B}}$ formulations were characterized according to their physical appearance, mean droplet size, polydispersity index, $\zeta$-potential, and viscosity and transmission electron microscopy (TEM). The mean droplet size and polydispersity index were determined by photon correlation spectroscopy at $25^{\circ} \mathrm{C}$, and the $\zeta$-potential was determined by electrophoretic mobility at $25^{\circ} \mathrm{C}$. The analyses were performed using Zetasizer NanoZS90 ${ }^{\circledR}$ equipment (Malvern Instruments, Malvern, UK) after dilution of the samples in water and $1 \mathrm{mM} \mathrm{NaCl}$ solution, respectively. The viscosity was performed by capillary viscometry using an Ostwald viscometer $\left(20^{\circ} \mathrm{C} \pm 0.1^{\circ} \mathrm{C}\right)$, and the morphological analysis of the formulations was conducted using transmission electron microscopy. The images were obtained using a JEM 1220EXII microscope (Jeol Ltd., Akishim, Japan).

The flavonoid content in each formulation was determined using the UFLC conditions described above (Section 2.2). Nanoemulsions were solubilized in methanol and diluted properly prior to UFLC analysis.

\subsection{Keratinocyte Cell Culture and Treatment}

$\mathrm{HaCaT}$ cells (immortalized human keratinocytes) were obtained from Thermo Fisher Scientific (Waltham, MA, USA). DMEM medium supplemented with $10 \%$ FBS was used for the culturing of the cells, which were maintained at $37{ }^{\circ} \mathrm{C}$ in a humidified $5 \% \mathrm{CO}_{2}$ atmosphere. Cells were seeded in 96 and 48 -well plates $\left(8 \times 10^{3}\right.$ and $1.5 \times 10^{4}$ cells per well, respectively) for the MTT, PI incorporation, and cell migration assays. The cultures were kept at $37{ }^{\circ} \mathrm{C}$ in a humidified $5 \% \mathrm{CO}_{2}$ atmosphere for $24 \mathrm{~h}$ and were further treated with ASE (previously dried and resuspended in dimethyl sulfoxide (DMSO)) and $\mathrm{NE}_{\mathrm{ASE}}$ 
at $0.625,1.25,2.5,5$, and $10 \mu \mathrm{g} / \mathrm{mL}$ concentrations. After $24 \mathrm{~h}$ of treatment, cell viability, death by necrosis, and migration were determined as follows.

\subsubsection{Cell Viability (MTT) Assay}

Cell viability was assessed using the dehydrogenase-dependent MTT reduction assay. This is a colorimetric assay to determine cell metabolic activity and viability. Following the treatment, the medium was removed and MTT solution $(5 \mathrm{mg} / \mathrm{mL})$ was added to the culture media at a final concentration of $0.5 \mathrm{mg} / \mathrm{mL}$. Cells were incubated for $60 \mathrm{~min}$ at $37{ }^{\circ} \mathrm{C}$ in a humidified $5 \% \mathrm{CO}_{2}$ atmosphere. The medium was then removed, and plates were shaken with DMSO for $30 \mathrm{~min}$. The absorbance was measured at $492 \mathrm{~nm}$ using a spectrophotometer SpectraMax ${ }^{\circledR}$ M2 (Molecular Devices, San Jose, CA, USA) [22]. Controls containing DMSO $(0.01 \%)$ and $\mathrm{NE}_{\mathrm{B}}$ were performed. Results were expressed as the percentage of the control.

\subsubsection{Propidium Iodide (PI) Assay}

Cell death by necrosis was analyzed with phase contrast and fluorescence microphotographs, observing morphological alterations (cell elongation and crenation) and/or PI incorporation. For this assay, cells were incubated with PI $(7.5 \mu \mathrm{M})$ for $60 \mathrm{~min}$ at the end of the treatment. An inverted microscope (Olympus IX71, Olympus Corporation, Shinjuku, Tokyo, Japan) fitted with a standard rhodamine filter was excited at 515 and $560 \mathrm{~nm}$ using PI fluorescence. Images were captured using a digital camera connected to the microscope. Controls containing DMSO $(0.01 \%)$ and $\mathrm{NE}_{\mathrm{B}}$ were performed. Results were expressed as a qualitative evaluation of morphological alterations and PI incorporation.

\subsubsection{Cell Migration}

Cell migration was investigated by the scratch-wound assay. The scratch was performed when the cell density reached $80 \%$, using a P200 pipette tip in the cell monolayer. The cells were then treated with ASE and $\mathrm{NE}_{\mathrm{ASE}}$ at $0.625,1.25,2.5,5$, and $10 \mu \mathrm{g} / \mathrm{mL}$ concentrations prepared in DMEM/0.5\% FBS. A control containing DMEM $/ 0.5 \%$ FBS was used. The scratch images were taken after $0,6,18$, and $24 \mathrm{~h}$. Images were captured using a digital camera connected to the microscope (Olympus IX71, Olympus Corporation, Shinjuku, Tokyo, Japan). ImageJ software (http://imagej.nih.gov/ij/, accessed on 2 July 2020) was employed for cell migration quantification, comparing this with the zero-time width. Four visual fields were randomly selected for each sample. The results were expressed as the mean percentage of migration in triplicates.

\subsection{Hen's Egg Chorioallantoic Membrane Test (HET-CAM)}

Fertilized hen's eggs were obtained from a local producer immediately after laying and were placed in an automatic rotary incubator (Chocar Chocadeiras, Conceição do Coité, Brazil) for 10 days under controlled temperature $\left(37.8 \pm 1.0^{\circ} \mathrm{C}\right)$ and relative humidity (45-65\%). On the 10th day, the eggs were candled to ensure the viability of the embryos. Defective or cracked eggs were discarded. The shell was then removed at the air cell with tweezers, and the inner membrane was withdrawn to reveal the highly vascularized chorioallantoic membrane (CAM).

Then, $0.3 \mathrm{~mL}$ of test substance $(n=5)$ was applied to the CAM and left in contact for $300 \mathrm{~s}$. The following groups were tested: $0.9 \% w / v \mathrm{NaCl}$ (negative control), $0.1 \mathrm{M} \mathrm{NaOH}$ (positive control for hemorrhage and coagulation), $1 \% w / v$ sodium lauryl sulfate (positive control for vasoconstriction), olive oil (negative control, applied to solubilize ASE) [23], ASE:olive oil 1:100 $(w / v)$ (ASE solubilized in olive oil in the same proportion as found in $\mathrm{NE}_{\mathrm{ASE}}$ ), $\mathrm{NE}_{\mathrm{B}}$ (blank nanoemulsion), and $\mathrm{NE}_{\mathrm{ASE}}$ (nanoemulsion containing ASE). Due to the opacity of the nanoemulsions, saline solution was used to rinse the CAM after $20 \mathrm{~s}$, 
facilitating the observation of vascular effects. The irritation score (IS) was calculated using Equation (1):

$$
\begin{gathered}
\text { IS }=[5 \times(301-\text { hemorrhage time in sec }) / 300]+[7 \times(301-\text { vasoconstriction } \\
\text { time in sec }) / 300]+[9 \times(301-\text { coagulation time in sec }) / 300]
\end{gathered}
$$

The IS was presented as the mean and relative standard deviation in percentage (RSD \%). The statistical analysis of the IS score was performed by a one-way analysis of variance (ANOVA) followed by Tukey's post hoc test $(p \leq 0.05)$. In addition, the damage to the hen's egg-chorioallantoic membrane was classified by the mean as non-irritant (0-0.9), slight irritant (1.0-4.9), moderate irritant (5-8.9), and extreme irritant (9-21) [24-26].

The HET-CAM assay was approved by The Animal Use Ethics Committee from UFRGS under protocol number 40087. All procedures were performed according to the Brazilian National Animal Care Ethical Council (CONCEA) guidelines and Law No. $11794 / 2008$ for the proper care and use of experimental animals.

\subsection{Statistical Analysis}

Results were expressed as the mean \pm standard deviation of at least three independent experiments. An ANOVA was used to compare the experimental data, and the Tukey post hoc test was used to discriminate the differences at a significance level of $p<0.05$. All analyses were conducted using Action Software (Version 2.5) or GraphPad Prism 5 Software.

\section{Results and Discussion}

\subsection{Physicochemical Characterization of Nanoemulsions}

The physicochemical properties of nanoemulsions obtained by the spontaneous emulsification procedure are presented in Table 1 . This procedure yielded monodispersed nanoemulsions (PDI < 0.12) exhibiting a droplet size in a range of 200-300 nm, according to the images obtained by transmission electron microscopy displayed in Figure 1. The incorporation of ASE into nanoemulsions led to a greater average droplet diameter and viscosity of the formulations. The wide variety of the compounds from ASE associated (into the oily core and/or oil/water interface) with the colloidal structure, as well as the possible interactions of these compounds with the phospholipids from egg-lecithin, may have an effect on the physicochemical properties of the nanoemulsion [19]. A higher negative $\zeta$-potential of $\mathrm{NE}_{\mathrm{ASE}}(-43 \mathrm{mV})$ was noticed in comparison with $\mathrm{NE}_{\mathrm{B}}(-21 \mathrm{mV})$. This result may be a consequence of the negatively charged phospholipids and free fatty acids in the egg yolk lecithin and the extract components located at the oil/water interface of the nanoemulsions, as phenolic acids [19].

Table 1. Physicochemical characterization of nanoemulsions.

\begin{tabular}{ccc}
\hline & NE $_{\mathbf{B}}$ & NE $_{\text {ASE }}$ \\
\hline Size $(\mathrm{nm})$ & $200 \pm 20$ & $307 \pm 11.0$ \\
Polydispersity index & $0.06 \pm 0.01$ & $0.12 \pm 0.01$ \\
$\zeta$-potential $(\mathrm{mV})$ & $-21.17 \pm 3.21$ & $-43.90 \pm 3.92$ \\
Viscosity $(\mathrm{cP})$ & $1.66 \pm 5.09$ & $2.32 \pm 2.9$ \\
Flavonoids content $(\mu \mathrm{g} / \mathrm{mL})$ & - & $1130.3 \pm 7.5^{*}$ \\
\hline
\end{tabular}

$\mathrm{NE}_{\mathrm{B}}$ : Blank nanoemulsion; $\mathrm{NE}_{\mathrm{ASE}}$ : nanoemulsion containing Achyrocline satureioides extract. ${ }^{*}$ The amount of each isolated flavonoid found was about $315 \mu \mathrm{g} / \mathrm{mL}$ of quercetin, $160 \mu \mathrm{g} / \mathrm{mL}$ of luteolin, and $618 \mu \mathrm{g} / \mathrm{mL}$ of 3-O-methylquercetin.

Prior to the evaluation of the flavonoids loading with nanoemulsions, the flavonoid content (QCT, LUT, and 3MQ) was estimated in the hydroethanolic extract by the UFLC method previously described. Overall, $251.70 \pm 10.86 \mu \mathrm{g} / \mathrm{mL}$ of QCT, $154.08 \pm 6.61 \mu \mathrm{g} / \mathrm{mL}$ of LUT, and $687.32 \pm 30.81 \mu \mathrm{g} / \mathrm{mL}$ of 3MQ was detected, in accordance with previous literature using similar extraction conditions [12,19]. Final formulations contained $1 \%(w / v)$ 
of $A$. satureioides dry residue. The flavonoid content in nanoemulsions exhibited a recovery close to $100 \%$, indicating a satisfactory recovery for all formulations. Overall results demonstrated that, under the conditions used in this study, nanoemulsions maintained the analyzed parameters and were consistent with our previous report [19], demonstrating that the experimental conditions were well controlled.
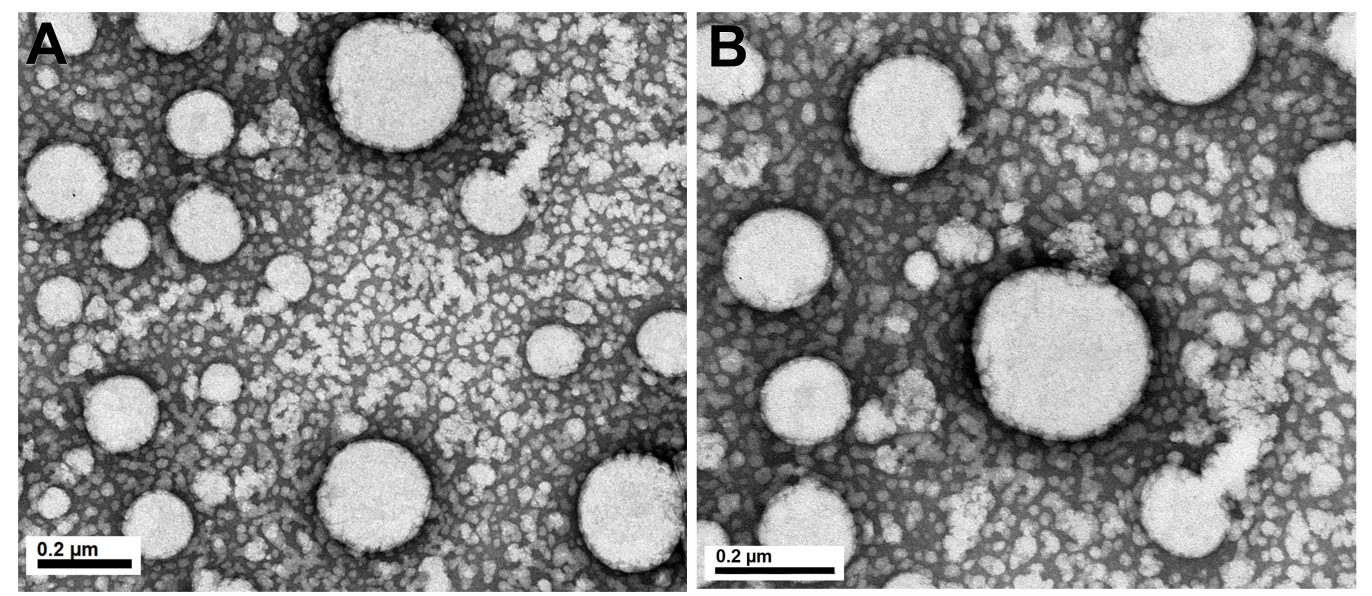

Figure 1. TEM images of nanoemulsion containing A. satureioides extract ( $\mathrm{NE}_{\mathrm{ASE}}$ ). Where: (A) $75 \mathrm{~K}$ increase and (B) $120 \mathrm{~K}$ increase.

\subsection{In Vitro Cell Viability and Migration Evaluation in Keratinocytes}

Cell viability was determined using the MTT assay to evaluate the safety profile and the ability of ASE to induce the proliferation of human keratinocytes $[27,28]$. As can be seen in Figure 2, the ASE did not induce HaCaT cytotoxicity but rather a tendency to increase the cell viability of keratinocytes when compared to the control after $24 \mathrm{~h}$ of treatment for all concentrations tested $(0.625-10 \mu \mathrm{g} / \mathrm{mL})$. This result agrees with a previous report for the aqueous and ethanolic ASE, which indicated the same tendency in keratinocytes over a concentration range of ASE between 1-50 $\mathrm{g} / \mathrm{mL}$ [13]. When ASE is incorporated into a nanoemulsion $\left(\mathrm{NE}_{\mathrm{ASE}}\right)$, a significant increase in cell viability is noticeable up to $5 \mu \mathrm{g} / \mathrm{mL}$ $(p<0.05)$. These results indicate that the incorporation of ASE in nanoemulsions is able to increase the cell viability, thus increasing the proliferative capacity of these cells when compared to treatment with the free extract (ASE).

Cell death by necrosis was assessed by the PI assay, which is used as a marker that permeates only damaged cell membranes. Intercalation complexes between PI and DNA are formed, which act by amplifying the fluorescence. The possibility of visualization of this fluorescence finally allows us to evaluate non-vital cells [29]. After $24 \mathrm{~h}$ of cell treatment with ASE and $\mathrm{NE}_{\mathrm{ASE}}$ (from 0.625 to $10 \mu \mathrm{g} / \mathrm{mL}$ ), the incorporation of PI and morphological alterations (cell elongation and crenation) for $A$. satureioides-treated cells was noticeable only at concentrations above $2.5 \mu \mathrm{g} / \mathrm{mL}$ (Figure 3 and Table 2), indicating that toxicity and cell death by necrosis occurred as a function of the extract concentration used. On the other hand, for the cells treated with $\mathrm{NE}_{\mathrm{ASE}}$, it was not possible to observe the incorporation of PI in any of the concentrations tested, indicating that there was no damage to the cell membrane treated with the formulations. These results suggested for the first time that the incorporation of the extract into a nanoemulsion may decrease cell death by necrosis. Additionally, although cell death by apoptosis was not observed in the MTT assay, the positive effect of the incorporation of ASE in nanoemulsions on cell proliferation was also demonstrated. Accordingly, Bidone et al. (2015) [12] previously reported a decrease in the toxicity of ASE when incorporated into nanoemulsions using Vero cells. 


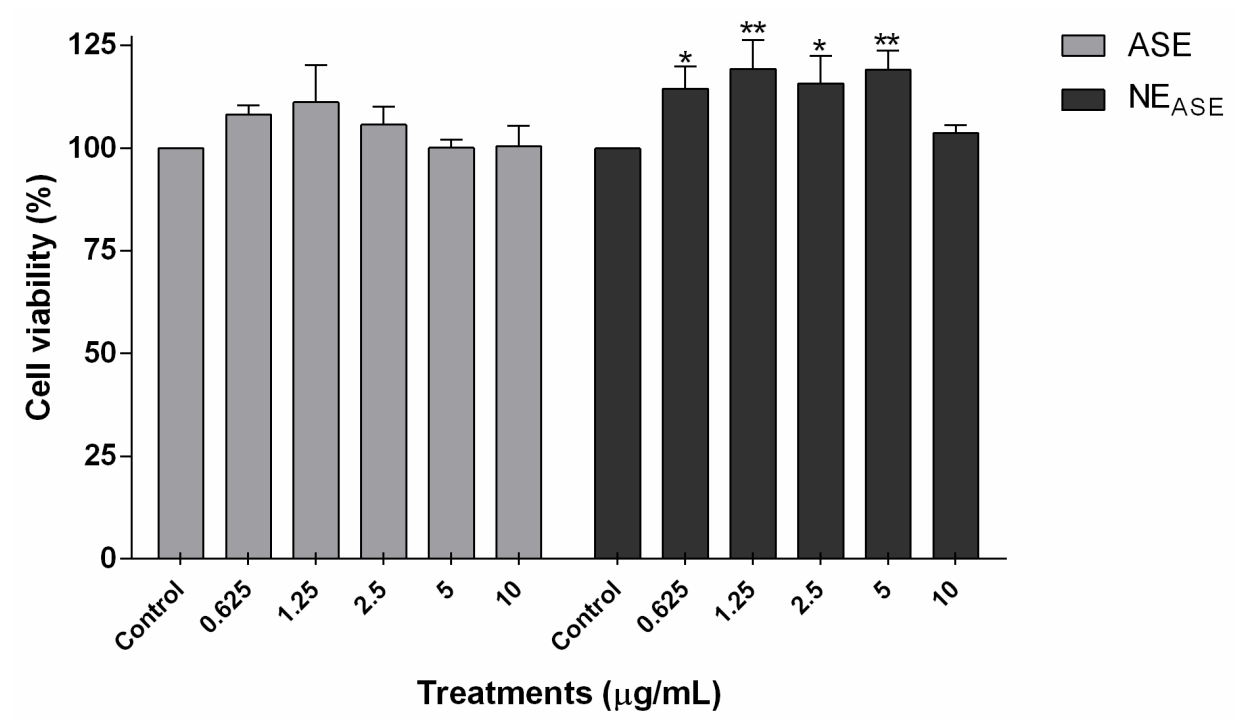

Figure 2. Cell viability (MTT assay) of HaCaT cells (immortalized human keratinocytes) after $24 \mathrm{~h}$ of treatment with ASE and $\mathrm{NE}_{\mathrm{ASE}}$ at $0.625,1.25,2.5,5$, and $10 \mu \mathrm{g} / \mathrm{mL}$ concentrations. Appropriate vehicle controls with DMSO $0.01 \%(v / v)$ and $\mathrm{NE}_{\mathrm{B}}$ were performed for ASE and $\mathrm{NE}_{\mathrm{ASE}}$ treatments, respectively. Value represents mean $\pm \mathrm{SD}$ for triplicate tests. Data were analyzed by a one-way analysis of variance followed by Tukey's post hoc test. ${ }^{*} p<0.05$, and ${ }^{* *} p<0.01$, different from control group. ASE: Achyrocline satureioides extract; $\mathrm{NE}_{\mathrm{ASE}}$ : Achyrocline satureioides extract-loaded nanoemulsion; $\mathrm{NE}_{\mathrm{B}}$ : blank nanoemulsion.

Table 2. Morphological alterations and PI incorporation in HaCaT cells (immortalized human keratinocytes) after $24 \mathrm{~h}$ of treatment with $\mathrm{ASE}$ and $\mathrm{NE}_{\mathrm{ASE}}$ at $0.625,1.25,2.5,5$, and $10 \mu \mathrm{g} / \mathrm{mL}$ concentrations.

\begin{tabular}{|c|c|c|c|c|c|c|c|}
\hline \multirow{2}{*}{\multicolumn{2}{|c|}{ Treatments }} & \multicolumn{6}{|c|}{ Concentrations $(\mu \mathrm{g} / \mathrm{mL})$} \\
\hline & & \multirow{2}{*}{$\frac{\text { Control }}{\text { No }}$} & \multirow{2}{*}{$\begin{array}{c}0.625 \\
\text { No }\end{array}$} & \multirow{2}{*}{$\begin{array}{l}1.25 \\
\text { No }\end{array}$} & \multirow{2}{*}{$\begin{array}{l}2.5 \\
\text { Yes }\end{array}$} & \multirow{2}{*}{$\frac{5}{\text { Yes }}$} & \multirow{2}{*}{$\begin{array}{c}10 \\
\text { Yes }\end{array}$} \\
\hline & M & & & & & & \\
\hline ASE & PI & No & No & No & Yes & Yes & Yes \\
\hline \multirow{2}{*}{$\mathrm{NE}_{\mathrm{ASE}}$} & $\mathrm{M}$ & No & No & No & No & No & No \\
\hline & PI & No & No & No & No & No & No \\
\hline
\end{tabular}

Appropriate vehicle controls with DMSO $0.01 \%(v / v)$ and $\mathrm{NE}_{\mathrm{B}}$ were performed for ASE and $\mathrm{NE}_{\mathrm{ASE}}$ treatments, respectively. M: morphological alterations (cell elongation and crenation); PI: propidium iodide incorporation; No: absent; Yes: present; ASE: Achyrocline satureioides extract; $\mathrm{NE}_{\mathrm{ASE}}$ : Achyrocline satureioides extract-loaded nanoemulsion; controls DMSO $(0.01 \%)$ and $\mathrm{NE}_{\mathrm{B}}$ : blank nanoemulsion.

Cell migration has great importance in the development and physiology of diseases. The scratch-wound model is an in vitro model that is often used to study re-epithelialization because it mimics aspects of keratinocyte migration in vivo. This assay combined the effects of proliferation and migration, both of which are important in wound healing [30,31]. This study was used to evaluate the migration of human keratinocytes (HaCaT), since they are cells that are directly involved in the wound healing process [32]. After scratching, it is possible to monitor cell migration with the support of a microscope, since the cells migrate from the intact region to the scattered region; images are obtained at $0,6,18$, and $24 \mathrm{~h}$ and expressed as percentage of migration. The effects of $\mathrm{NE}_{\mathrm{ASE}}$ and ASE on cell migration were evaluated and can be observed in Figure 4. 

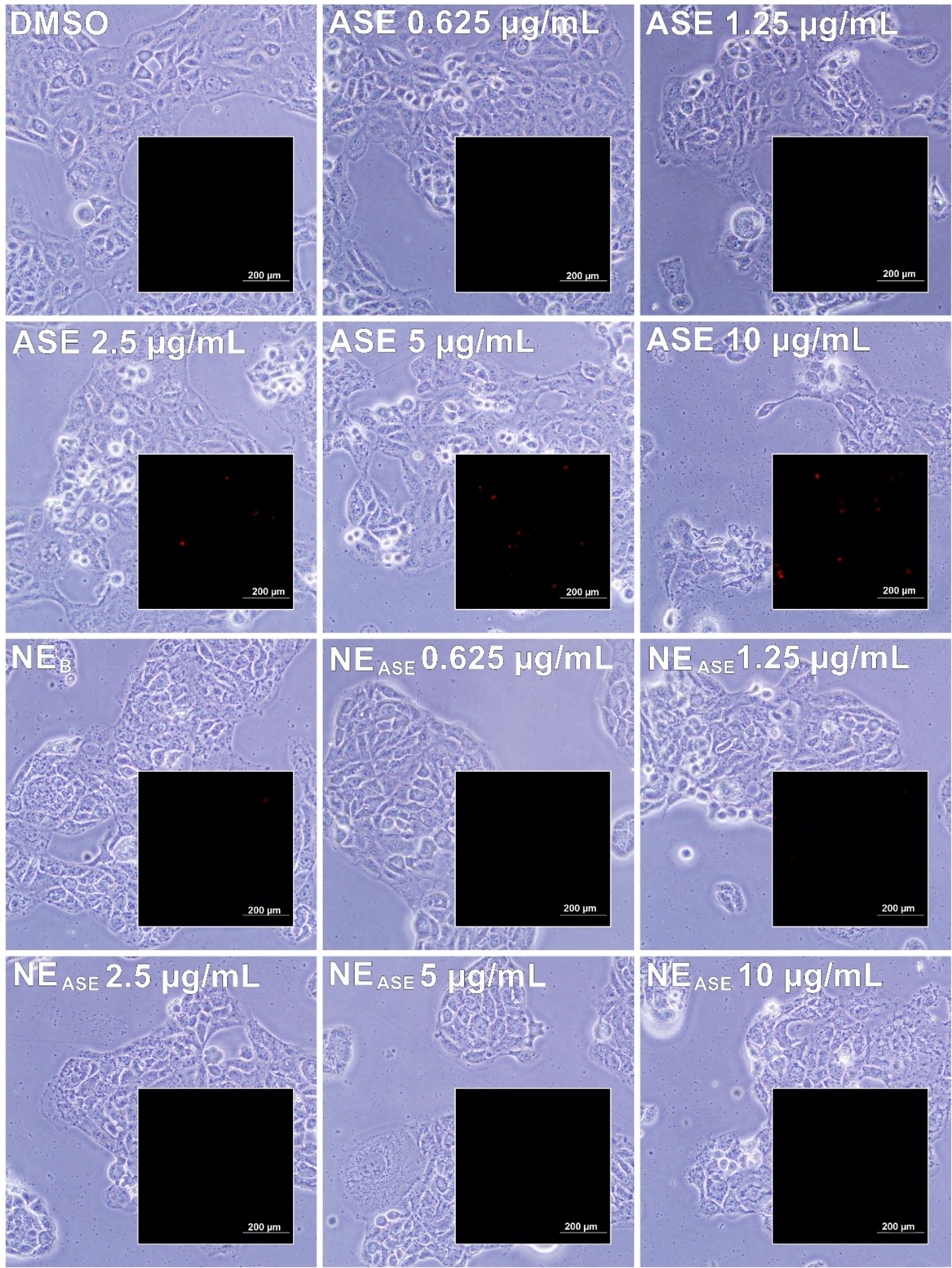

Figure 3. Phase contrast and fluorescence microphotographs (insert) of PI incorporation in HaCaT cells (immortalized human keratinocytes) after $24 \mathrm{~h}$ of treatment with $\mathrm{ASE}$ and $\mathrm{NE}_{\mathrm{ASE}}$ at $0.625,1.25,2.5,5$, and $10 \mu \mathrm{g} / \mathrm{mL}$ concentrations. Appropriate vehicle controls with DMSO $0.01 \%(v / v)$ and $\mathrm{NE}_{\mathrm{B}}$ were performed for ASE and $\mathrm{NE}_{\mathrm{ASE}}$ treatments, respectively. ASE: Achyrocline satureioides extract; $\mathrm{NE}_{\mathrm{ASE}}$ : Achyrocline satureioides extract-loaded nanoemulsion; $\mathrm{NE}_{\mathrm{B}}$ : blank nanoemulsion. 

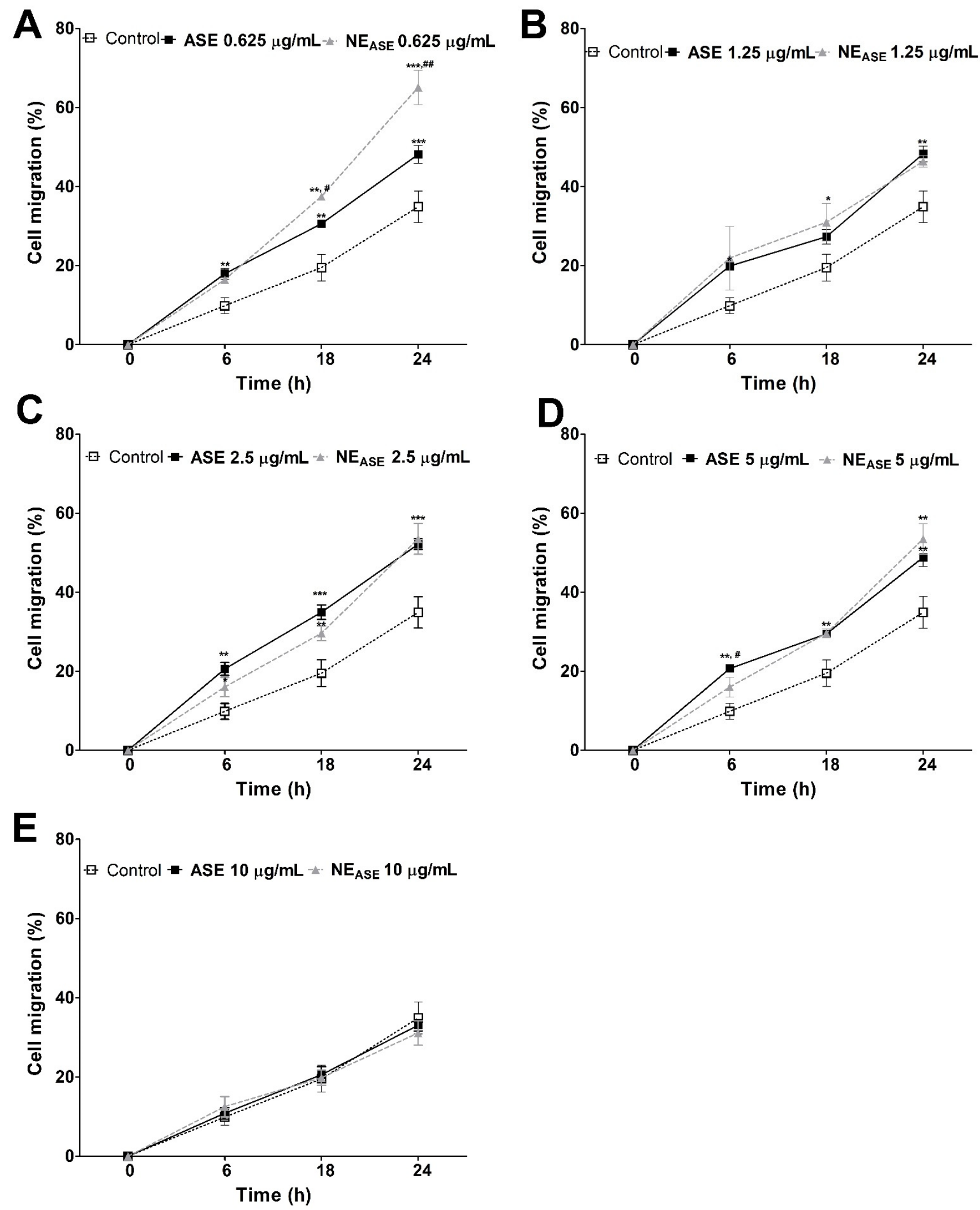

Figure 4. Cell migration (\%) of HaCaT (immortalized human keratinocytes) after 6, 18, and 24 h of treatment with ASE and $\mathrm{NE}_{\mathrm{ASE}}$ at $0.625(\mathrm{~A}), 1.25$ (B), 2.5 (C), 5 (D), and 10 (E) $\mu \mathrm{g} / \mathrm{mL}$ concentrations. Untreated control group was performed. Value represent mean \pm SD for triplicate tests. Data were analyzed by one-way analysis of variance followed by Tukey's post hoc test. ${ }^{*} p<0.05,{ }^{* *} p<0.01$, and ${ }^{* * *} p<0.001$, different from control group; ${ }^{\#} p<0.05$, and ${ }^{\# \#} p<0.01$, different from ASE group. ASE: Achyrocline satureioides extract; $\mathrm{NE}_{\mathrm{ASE}}$ : Achyrocline satureioides extract-loaded nanoemulsion. 
At the lowest concentration used $(0.625 \mu \mathrm{g} / \mathrm{mL}), \mathrm{NE}_{\mathrm{ASE}}$ exerted a positive effect on the migration of keratinocytes over the scratching when compared to ASE and the control group at 6,18 , and $24 \mathrm{~h}$. From the $1.25 \mu \mathrm{g} / \mathrm{mL}$ concentration, there is a decrease in the migration of $\mathrm{NE}_{\mathrm{ASE}^{-}}$-treated samples; this behavior is similar to ASE, but still represents a positive effect on the migration of keratinocytes in comparison to the control. However, only at the highest concentration $(10 \mu \mathrm{g} / \mathrm{mL})$ was there no evidence of an increase in the migration of $\mathrm{NE}_{\mathrm{ASE}}$ and ASE-treated cells when compared to the control (untreated cellsDMEM $/ 0.5 \%$ FBS). It should be noted that the scratch assay was conducted by maintaining the cells at $0.5 \%$ FBS to minimize cell proliferation. Overall, the results indicate that $\mathrm{NE}_{\mathrm{ASE}}$ exerts a positive effect on cell migration, depending on the concentration, which is a key consideration, as an increased cell migration rate and wound closure may have a crucial effect on the topical wound healing activity [33].

\subsection{Hen's Egg Chorioallantoic Membrane Test (HET-CAM)}

The HET-CAM test has been widely used as an alternative methodology to the in vivo ocular irritation test. In recent years, it has also been employed as a preliminary screening test before in vivo study to provide the irritant potential of substances on membranes and skin $[24,26,34]$.

Results for irritant potential are shown in Figure 5 and Table 3. Before testing the ASE and the developed nanoemulsions, positive and negative controls were evaluated for vascular effects. The IS scores for the positive controls, $\mathrm{NaOH} 0.1 \mathrm{M} \mathrm{w} / v$ and sodium lauryl sulfate $1 \% w / v$, were 13.26 and 10.51, respectively, meaning that these can be considered as extreme irritants (Table 3). Additionally, as expected, the negative controls, $\mathrm{NaCl} 0.9 \% w / v$ and olive oil, presented no irritant reactions. Furthermore, for $\mathrm{NE}_{\mathrm{B}}$, no irritant effect was evidenced, suggesting that the surfactants are safe for topical application (Figure 5). Regarding ASE, no vascular reaction was noted, whether or not it was associated with a nanostructure (NE $\mathrm{NSE}_{\text {) }}$ (Table 3 and Figure 5). These results are promising as the nanoemulsion containing ASE showed an absence of vascular alterations in the CAM, which are the first changes associated with skin irritation, in comparison with the negative control $\mathrm{NaCl} 0.9 \% w / v(p \geq 0.05)$ (Table 3 and Figure 5). The non-irritative potential shown above, added to the results obtained with cell viability assessments, suggests that the developed ASE-loaded nanoemulsion can be safely applied by the topical route [35], including application to damaged skin.
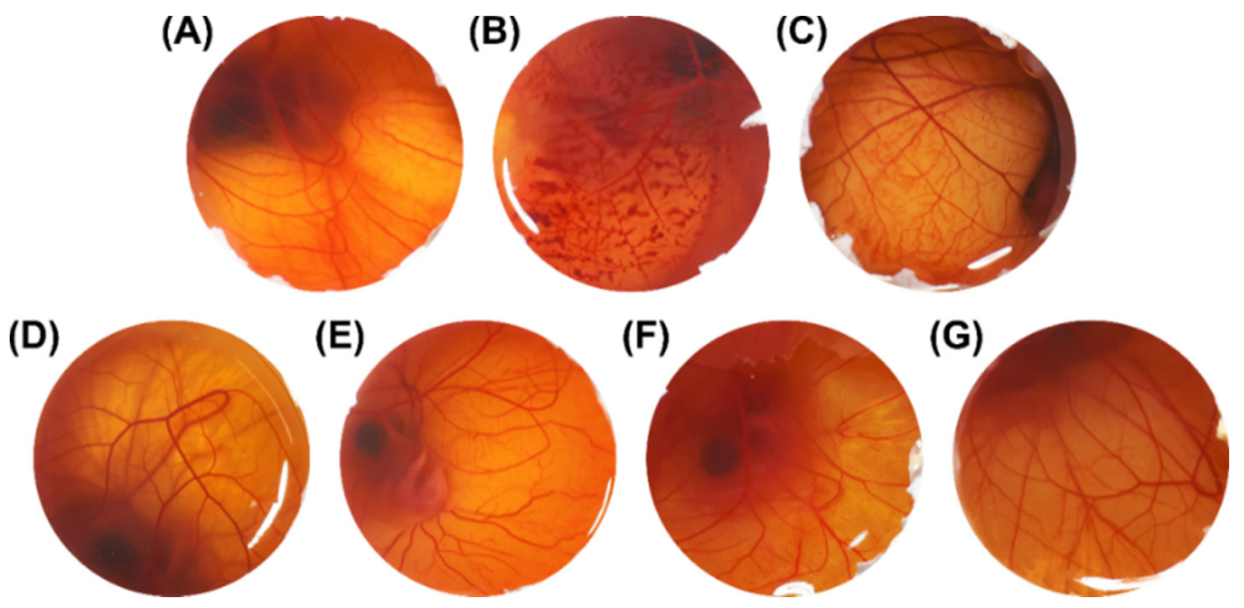

Figure 5. Images illustrating the effects of different substances applied on the chorioallantoic membrane over a 5 min period (1× magnification). (A) $\mathrm{NaCl} 0.9 \% w / v,($ B) $\mathrm{NaOH} 0.1 \mathrm{M}$, (C) Sodium lauryl sulfate $1 \% w / v$, (D) Olive oil (negative control), (E) ASE solubilized in olive oil, (F) $\mathrm{NE}_{\mathrm{B}}$, (G) $\mathrm{NE}_{\mathrm{ASE}}$. ASE: Achyrocline satureioides extract; $\mathrm{NE}_{\mathrm{B}}$ : blank nanoemulsion; $\mathrm{NE}_{\mathrm{ASE}}$ : Achyrocline satureioides extract-loaded nanoemulsion. 
Table 3. Irritant score and irritancy classification in the hen's egg chorioallantoic membrane test $(\operatorname{HET}-\mathrm{CAM})(n=5)$.

\begin{tabular}{ccc}
\hline Substance & IS (RSD \%) & Classification \\
\hline $\mathrm{NaCl} 0.9 \% w / v$ & $0(0)$ & Non-irritant \\
$\mathrm{NaOH} 0.1 \mathrm{M}$ & $13.26(1.41)^{*}$ & Extreme irritant \\
Sodium lauryl sulfate $1 \% w / v$ & $10.51(2.29)^{*}$ & Extreme irritant \\
Olive oil & $0(0)$ & Non-irritant \\
ASE:Olive oil $(1: 100) w / v$ & $0(0)$ & Non-irritant \\
$\mathrm{NE}_{\mathrm{B}}$ & $0(0)$ & Non-irritant \\
$\mathrm{NE}_{\mathrm{ASE}}$ & $0(0)$ & Non-irritant
\end{tabular}

IS: irritation score; RSD \%: relative standard deviation in percentage; ASE: Achyrocline satureioides extract; $\mathrm{NE}_{\mathrm{B}}$ blank nanoemulsion; $\mathrm{NE}_{\mathrm{ASE}}$ : Achyrocline satureioides extract-loaded nanoemulsion. * Statistically different from $\mathrm{NaCl} 0.9 \% w / v$ (negative control group) $(p<0.05)$.

\section{Conclusions}

An ASE-loaded nanoemulsion was prepared in order to investigate the in vitro cytotoxicity profile, proliferative effect, and migration ability in immortalized human keratinocytes (HaCaT cell line), as well as the HET-CAM irritant potential. The results showed an increase in cell viability when ASE was incorporated in nanoemulsions ( $\mathrm{NE}_{\mathrm{ASE}}$ ). The evaluation of PI incorporation indicated that there was no cell death due to necrosis when treated with $\mathrm{NE}_{\mathrm{ASE}}$ and suggested that the incorporation of the extract into the nanoemulsion may decrease the ASE toxicity induced by necrosis and increase its proliferation ability. Additionally, the scratch assay indicated that $\mathrm{NE}_{\mathrm{ASE}}$ was able to increase the cell migration rate and wound closure when compared to ASE and thus may play an important role in topical wound healing activity. We can also verify that the ASE and $\mathrm{NE}_{\mathrm{ASE}}$ did not present an irritant potential, as demonstrated by the HET-CAM test. In summary, these results indicate the potential of the proposed formulation for topical use in wound healing, in view of the promising effects regarding proliferation and migration in keratinocytes, combined with the suggestive absence of cytotoxicity in vitro and the non-irritant potential.

Author Contributions: Conceptualization, L.A.B., H.F.T.; methodology, L.A.B., T.K., F.N.S.F., J.B., N.E.G.; formal analysis, L.A.B., T.K., F.N.S.F., N.E.G.; investigation, L.A.B., T.K., F.N.S.F., N.E.G.; writing—original draft preparation, L.A.B.; writing—review and editing, L.A.B., T.K., F.N.S.F., J.B., N.E.G., L.S.K., V.L.B., E.B., C.L.D., H.F.T.; visualization, L.A.B., T.K., F.N.S.F., J.B., L.S.K., V.LB., E.B., C.L.D., H.F.T.; supervision, H.F.T.; project administration, H.F.T.; funding acquisition, E.B., H.F.T. All authors have read and agreed to the published version of the manuscript.

Funding: This study was financed in part by the Conselho Nacional de Desenvolvimento Científico e Tecnológico (CNPq-process numbers 459619/2014-4; 312187/2018-1; 400882/2019-1) and the Coordenação de Aperfeiçoamento de Pessoal de Nível Superior-Brasil (CAPES-Finance Code 001). The article processing charges were founded by PROEX-CAPES project number 23038.006270/2019-11).

Conflicts of Interest: The authors declare no conflict of interest.

\section{References}

1. Calixto, J.B. The role of natural products in modern drug discovery. An. Acad. Bras. Cienc. 2019, 91, 1-7. [CrossRef] [PubMed]

2. Pazyar, N.; Yaghoobi, R.; Rafiee, E.; Mehrabian, A.; Feily, A. Skin wound healing and phytomedicine: A review. Skin Pharmacol. Physiol. 2014, 27, 303-310. [CrossRef] [PubMed]

3. Atanasov, A.G.; Zotchev, S.B.; Dirsch, V.M.; Orhan, I.E.; Banach, M.; Rollinger, J.M.; Barreca, D.; Weckwerth, W.; Bauer, R.; Bayer, E.A.; et al. Natural products in drug discovery: Advances and opportunities. Nat. Rev. Drug Discov. 2021, 20, 200-216. [CrossRef] [PubMed]

4. Elkordy, A.A.; Haj-Ahmad, R.R.; Awaad, A.S.; Zaki, R.M. An overview on natural product drug formulations from conventional medicines to nanomedicines: Past, present and future. J. Drug Deliv. Sci. Technol. 2021, 63, 102459. [CrossRef]

5. Sun, Y.; Qian, J. Botanical drug clinical trial: Common issues and future options. Acta Pharm. Sin. B 2021, 11, 300-303. [CrossRef]

6. Gertsch, J. Botanical drugs, synergy, and network pharmacology: Forth and back to intelligent mixtures. Planta Med. 2011, 77, 1086-1098. [CrossRef] [PubMed]

7. Retta, D.; Dellacassa, E.; Villamil, J.; Suárez, S.A.; Bandoni, A.L. Marcela, a promising medicinal and aromatic plant from Latin America: A review. Ind. Crops Prod. 2012, 38, 27-38. [CrossRef] 
8. Morquio, A.; Rivera-Megret, F.; Dajas, F. Photoprotection by topical application of Achyrocline satureioides ('Marcela'). Phyther. Res. 2005, 19, 486-490. [CrossRef]

9. Simões, C.M.O.; Schenkel, E.P.; Bauer, L.; Langeloh, A. Pharmacological investigations on Achyrocline satureioides (Lam.) DC., compositae. J. Ethnopharmacol. 1988, 22, 281-293. [CrossRef]

10. De Souza, K.C.B.; Bassani, V.L.; Schapoval, E.E.S. Influence of excipients and technological process on anti-inflammatory activity of quercetin and Achyrocline satureioides (Lam.) D.C. extracts by oral route. Phytomedicine 2007, 14, 102-108. [CrossRef]

11. Bettega, J.M.R.; Teixeira, H.; Bassani, V.L.; Barardi, C.R.M.; Simões, C.M.O. Evaluation of the antiherpetic activity of standardized extracts of Achyrocline satureioides. Phyther. Res. 2004, 18, 819-823. [CrossRef] [PubMed]

12. Bidone, J.; Argenta, D.F.; Kratz, J.; Pettenuzzo, L.F.; Horn, A.P.; Koester, L.S.; Bassani, V.L.; Simões, C.M.O.; Teixeira, H.F Antiherpes Activity and Skin/Mucosa Distribution of Flavonoids from Achyrocline satureioides Extract Incorporated into Topical Nanoemulsions. Biomed Res. Int. 2015, 2015. [CrossRef] [PubMed]

13. Alerico, G.C.; Beckenkamp, A.; Vignoli-Silva, M.; Buffon, A.; Von Poser, G.L. Proliferative effect of plants used for wound healing in Rio Grande do Sul state, Brazil. J. Ethnopharmacol. 2015, 176, 305-310. [CrossRef]

14. Pereira, L.X.; Silva, H.K.C.; Longatti, T.R.; Silva, P.P.; Di Lorenzo Oliveira, C.; de Freitas Carneiro Proietti, A.B.; Thomé, R.G.; do Carmo Vieira, M.; Carollo, C.A.; Demarque, D.P.; et al. Achyrocline alata potentiates repair of skin full thickness excision in mice. J. Tissue Viability 2017, 26, 289-299. [CrossRef] [PubMed]

15. Doersch, K.M.; Newell-Rogers, M.K. The impact of quercetin on wound healing relates to changes in $\alpha \mathrm{V}$ and $\beta 1$ integrin expression. Exp. Biol. Med. 2017, 242, 1424-1431. [CrossRef]

16. Yin, G.; Wang, Z.; Wang, Z.; Wang, X. Topical application of quercetin improves wound healing in pressure ulcer lesions. Exp. Dermatol. 2018, 27, 779-786. [CrossRef]

17. Ozay, Y.; Guzel, S.; Erdogdu, I.H.; Yildirim, Z.; Pehlivanoglu, B.; Turk, B.A.; Darcan, S. Evaluation of the wound healing properties of luteolin ointments on excision and incision wound models in diabetic and non-diabetic rats. Rec. Nat. Prod. 2018, 12, 350-366. [CrossRef]

18. Carvalho, E.L.S.; Zorzi, G.K.; Von Poser, G.L.; Teixeira, H.F.; Moreira, J.C.F.; Bassani, V.L. Nanoestrutura compreendendo extratos vegetais, processo deprodução de nanoestrutura compreendendo extratos vegetais e composições compreendendo as mesmas. Brazil Patent BR PI0805156A2 I, 20 November 2008.

19. Bidone, J.; Zorzi, G.K.; Carvalho, E.L.S.; Simões, C.M.O.; Koester, L.S.; Bassani, V.L.; Teixeira, H.F. Incorporation of Achyrocline satureioides (Lam.) DC extracts into topical nanoemulsions obtained by means of spontaneous emulsification procedure. Ind. Crops Prod. 2014, 62, 421-429. [CrossRef]

20. Balestrin, L.A.; Bidone, J.; Bortolin, R.C.; Moresco, K.; Moreira, J.C.; Teixeira, H.F. Protective effect of a hydrogel containing Achyrocline satureioides extract-loaded nanoemulsion against UV-induced skin damage. J. Photochem. Photobiol. B Biol. 2016, 163, 269-276. [CrossRef]

21. Balestrin, L.A.; Fachel, F.N.S.; Koester, L.S.; Bassani, V.L.; Teixeira, H.F. A stability-indicating ultra-fast liquid chromatography method for the assay of the main flavonoids of Achyrocline satureioides (Marcela) in porcine skin layers and nanoemulsions. Phytochem. Anal. 2020, 1-10. [CrossRef]

22. Fachel, F.N.S.; Medeiros-Neves, B.; Dal Prá, M.; Schuh, R.S.; Veras, K.S.; Bassani, V.L.; Koester, L.S.; Henriques, A.T.; Braganhol, E.; Teixeira, H.F. Box-Behnken design optimization of mucoadhesive chitosan-coated nanoemulsions for rosmarinic acid nasal delivery-In vitro studies. Carbohydr. Polym. 2018, 199, 572-582. [CrossRef] [PubMed]

23. Koch, C.; Reichling, J.; Kehm, R.; Sharaf, M.M.; Zentgraf, H.; Schneele, J.; Schnitzler, P. Efficacy of anise oil, dwarf-pine oil and chamomile oil against thymidine-kinase-positive and thymidine-kinase-negative herpesviruses. J. Pharm. Pharmacol. 2008, 60, 1545-1550. [CrossRef]

24. Luepke, N.P. Hen's egg chorioallantoic membrane test for irritation potential. Food Chem. Toxicol. 1985, 23, 287-291. [CrossRef]

25. ICCVAM Recommended Test Method Protocol: Hen's Egg Test—Chorioallantoic Membrane (HET-CAM) Test Method. NIH Publication No. 10-7553. 2010. Available online: https://ntp.niehs.nih.gov/iccvam/docs/protocols/ivocular-hetcam.pdf (accessed on 13 May 2021).

26. Pereira, R.L.; Leites, F.I.; Paese, K.; Sponchiado, R.M.; Michalowski, C.B.; Guterres, S.S.; Schapoval, E.E.S. Hydrogel containing adapalene- and dapsone-loaded lipid-core nanocapsules for cutaneous application: Development, characterization, in vitro irritation and permeation studies. Drug Dev. Ind. Pharm. 2016, 42, 2001-2008. [CrossRef]

27. Mosmann, T. Rapid Colorimetric Assay for Cellular Growth and Survival: Application to Proliferation and Cytotoxicity Assays. J Lmmunological Methods 1983, 65, 55-63. [CrossRef]

28. Chassot, J.M.; Ribas, D.; Silveira, E.F.; Grünspan, L.D.; Pires, C.C.; Farago, P.V.; Braganhol, E.; Tasso, L.; Cruz, L. Beclomethasone Dipropionate-Loaded Polymeric Nanocapsules: Development, In Vitro Cytotoxicity, and In Vivo Evaluation of Acute Lung Injury. J. Nanosci. Nanotechnol. 2015, 15, 855-864. [CrossRef]

29. Dengler, W.A.; Schulte, J.; Berger, D.P.; Mertelsmann, R.; Fiebig, H.H. Development of a propidium iodide fluorescence assay for proliferation and cytotoxicity assays. Anticancer. Drugs 1995, 6, 522-532. [CrossRef]

30. Gottrup, F.; Ågren, M.S.; Karlsmark, T. Models for use in wound healing research: A survey focusing on in vitro and in vivo adult soft tissue. Wound Repair Regen. 2000, 8, 83-96. [CrossRef] [PubMed]

31. Liang, C.C.; Park, A.Y.; Guan, J.L. In vitro scratch assay: A convenient and inexpensive method for analysis of cell migration in vitro. Nat. Protoc. 2007, 2, 329-333. [CrossRef] [PubMed] 
32. Cheng, F.; Shen, Y.; Mohanasundaram, P.; Lindström, M.; Ivaska, J.; Ny, T.; Erikss, J.E. Vimentin coordinates fibroblast proliferation and keratinocyte differentiation in wound healing via TGF- $\beta$-Slug signaling. Proc. Natl. Acad. Sci. USA 2016, 113, E4320-E4327. [CrossRef]

33. Shanmugapriya, K.; Kim, H.; Saravana, P.S.; Chun, B.S.; Kang, H.W. Astaxanthin-alpha tocopherol nanoemulsion formulation by emulsification methods: Investigation on anticancer, wound healing, and antibacterial effects. Colloids Surf. B Biointerfaces 2018, 172, 170-179. [CrossRef] [PubMed]

34. Luepke, N.P.; Kemper, F.H. The HET-CAM test: An alternative to the draize eye test. Food Chem. Toxicol. 1986, 24, 495-496. [CrossRef]

35. Reis Mansur, M.C.P.P.; Leitão, S.G.; Cerqueira-Coutinho, C.; Vermelho, A.B.; Silva, R.S.; Presgrave, O.A.F.; Leitão, Á.A.C.; Leitão, G.G.; Ricci-Júnior, E.; Santos, E.P. In vitro and in vivo evaluation of efficacy and safety of photoprotective formulations containing antioxidant extracts. Rev. Bras. Farmacogn. 2016, 26, 251-258. [CrossRef] 